GROUND-WATER DATA FROM THE SAN MIGUEL

RIVER BASIN, SOUTHWESTERN COLORADO

By D. J. Ackerman and Tom Brooks

U.S. GEOLOGICAL SURVEY

Open-File Report 85-191

Prepared in cooperation with the

COLORADO DEPARTMENT OF NATURAL RESOURCES,

DIVISION OF WATER RESOURCES, OFFICE OF THE STATE ENGINEER

Lakewood, Colorado

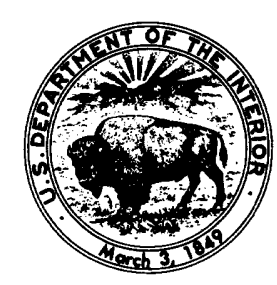




\section{UNITED STATES DEPARTMENT OF THE INTERIOR \\ DONALD PAUL HODEL, Secretary}

GEOLOGICAL SURVEY

Dallas L. Peck, Director

For additional information

write to:

District Chief

U.S. Geological Survey

Water Resources Division

Box 25046, Mail Stop 415

Denver Federal Center

Lakewood, CO 80225
Copies of this report can be purchased from:

Open-File Services Section Western Distribution Branch U.S. Geological Survey, MS 306 Box 25425, Denver Federal Center Denver, CO 80225

Telephone: (303) 236-7476 


\section{O N T E N T S}

Page

Glossary-

Abstract-1 1

Introduction- 1

Acknowledgments-1 3

System of numbering wells and springs-

References-_. 5

Hydrologic data- 6

Plate 1. Map showing location of data-collection sites,

Page

San Miguel River basin, southwestern Colorado-....... In pocket

Figure 1. Map showing location of the San Miguel River basin-_-_- 2

2. Diagram showing system of numbering wells and springs-..-.- 4

\section{TABLES}

Table 1. Hydrologic data from wells based on drillers' records-..-.-. 7

2. Hydrologic data for wells 10

3. Hydrologic data for springs- 11

4. Chemical analyses of water samples from wells and springs--.- 14 


\section{GLOSSARY}

Aquifer--a geologic formation, group of formations, or part of a formation that contains sufficient saturated permeable material to yield significant quantities of water to wells and springs.

Sodium-adsorption ratio (SAR)--is the expression of relative activity of sodium ions in exchange reactions with soil. The formula used for the computation of SAR is

$$
\mathrm{SAR}=\frac{(\mathrm{Na}+)}{\sqrt{\frac{\left(\mathrm{Ca}{ }^{+2}+\left(\mathrm{Mg}^{+2}\right)\right.}{2}}}
$$

where solute concentrations are expressed in milliequivalents per liter. Specific capacity-a measure of the productive capacity of the well.

The specific capacity of a water well is expressed as the rate of discharge divided by the drawdown. For example: if the pumping rate is 20 gallons per minute and the drawdown is measured as 10 feet after 2 hours of pumping, the specific capacity is 2 gallons per minute per foot at the end of 2 hours:

$$
\frac{20 \text { gallons per minute }}{10 \text { feet }}=2 \text { gallons per minute per foot }
$$

Specific conductance--a measure of the ability of water to conduct an electrical current, expressed in microsiemens per centimeter at $25^{\circ}$ Celsius. 
Inch-pound units used in this report may be converted to International Systems of Units (SI) by using the following conversion factors:

Multiply inch-pound units

foot $(\mathrm{ft})$

gallon per minute (gal/min)

gallon per minute per foot $[(\mathrm{gal} / \mathrm{min}) / \mathrm{ft}]$
By

0.3048

0.06309

0.01923
To obtain SI units

meter

liter per second

liter per second per meter

To convert degrees Fahrenheit $\left({ }^{\circ} \mathrm{F}\right)$ to degrees Celsius $\left({ }^{\circ} \mathrm{C}\right)$ use the following formula: ${ }^{\circ} \mathrm{C}=\left({ }^{\circ} \mathrm{F}-32\right) \times 5 / 9$. To convert degrees Celsius $\left({ }^{\circ} \mathrm{C}\right)$ to degrees Fahrenheit $\left({ }^{\circ} \mathrm{F}\right)$ use the following formula: ${ }^{\circ} \mathrm{F}=\left({ }^{\circ} \mathrm{Cx} 9 / 5\right)+32$.

The following terms and abbreviations also are used in this report:

microgram per liter $(\mu g / L)$

microsiemen per centimeter $(\mu \mathrm{s} / \mathrm{cm})$ at $25^{\circ}$ Celsius

milligram per liter $(\mathrm{mg} / \mathrm{L})$. 


\title{
GROUND-WATER DATA FROM THE SAN MIGUEL RIVER BASIN, SOUTHWESTERN COLORADO
}

\author{
By \\ D. F. Ackerman and Tom Brooks
}

\begin{abstract}
Hydrologic data were collected from 35 wells and 82 springs in the San Miguel River basin from 1977 to 1979. Depth to water was measured for 22 wells and discharges were measured for 53 springs. Chemical analyses for water samples collected from 19 wells and 21 springs indicated larger dissolved solids concentrations in bedrock water samples than in alluvial water samples. Drillers' records obtained from the Colorado State Engineer's Office for 86 wells indicated generally larger yields from wells completed in alluvium than in bedrock.
\end{abstract}

\section{INTRODUCTION}

This report includes hydrologic data for wells and springs in the San Miguel River basin in southwestern Colorado (fig. 1) and supplements the interpretive report by Ackerman and Rush (1984). Most of the data were collected from 1977 to 1979.

Data in this report consists of:

1. Hydrologic data from 86 wells based on well drillers' records obtained from the Colorado State Engineer's office (table 1).

2. Hydrologic data obtained from U.S. Geological Survey ground-water site investigation records for 35 wells (table 2) and 82 springs (table 3). Data for these sites were verified by field visits.

3. Chemical analyses of water samples collected from 19 wells and 21 springs (table 4). The water samples were collected and analyzed according to the method in Skoukstad and others (1979) and a11 constituents were analysed for dissolved concentrations at the U.S. Geological Survey Central laboratory. 


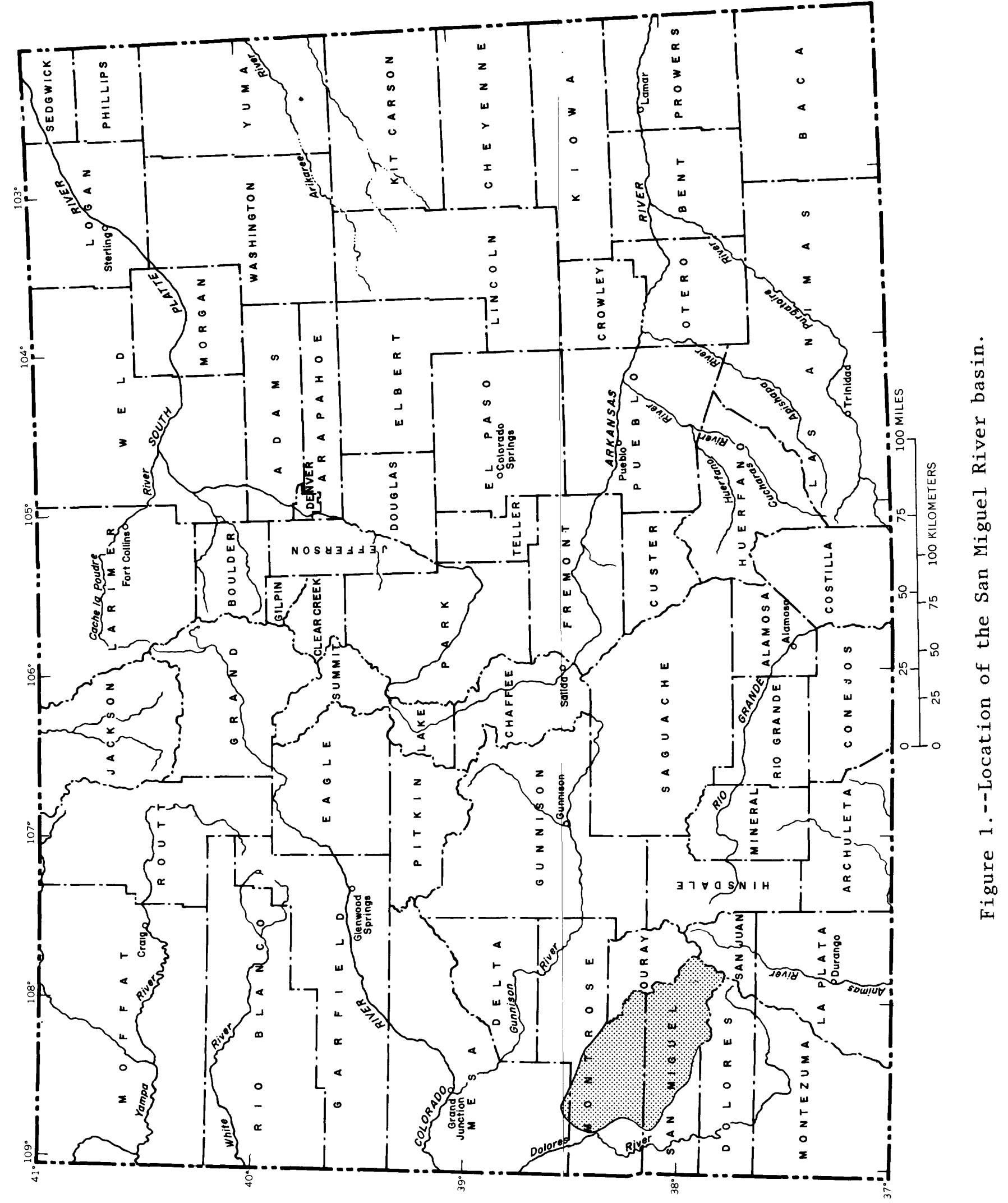


Data tables 1, 2, 3, and 4 are in the "Hydrologic Data" section of this report. All data sites are shown on plate 1 (in pocket).

Reported yields for wells completed in bedrock ranged from 0 to 216 gallons per minute with most yields less than $10 \mathrm{gal} / \mathrm{min}$. Reported yields for wells completed in alluvium ranged from 1.5 to $25 \mathrm{gal} / \mathrm{min}$ with most yields between 8 and $25 \mathrm{gal} / \mathrm{min}$.

Most dissolved solids concentrations were greater than $400 \mathrm{mg} / \mathrm{L}$ for water samples collected from wells completed in bedrock or springs issuing from bedrock; concentrations were less than $400 \mathrm{mg} / \mathrm{L}$ for water samples collected from wells completed in alluvium or springs issuing from alluvium.

\section{Acknowledgments}

Basin residents gave information about their wells and springs, and permitted measurements and water sampling. Donald Fawcett and Andrew Wacinski of the State Engineer's Office, and Stanley Zawistowski, formerly of the State Engineer's office, assisted in collecting and compiling data for this report.

\section{System of numbering wells and springs}

The well and spring locations in this report are given numbers based on the U.S. Bureau of Land Management system of land subdivision, and show the location of the well or spring by quadrant, township, range, section, and position within the section (fig. 2). The first letter "S" preceding the location number indicates that the well or spring is located in the area governed by the Sixth Principal Meridian. The second letter indicates the quadrant in which the well or spring is located. Four quadrants are formed by the intersection of the base line and the principal meridian--A indicates the northeast quadrant, $B$ the northwest, $C$ the southwest, and $D$ the southeast.

The first three digits of the number indicate the township, the next three digits the range, and the last two digits the section in which the well or spring is located. The letters following the section number locate the well or spring within the section. The first letter denotes the quarter section, the second the quarter-quarter section, and the third the quarter-quarter-quarter section. The letters are assigned within the section in a counterclockwise direction, beginning with (A) in the northeast section and within each quarter-quarter section in the same manner. Where two or more locations are within the smallest subdivision, consecutive numbers beginning with 1 are added in the order in which the data from the wells or springs were collected. 


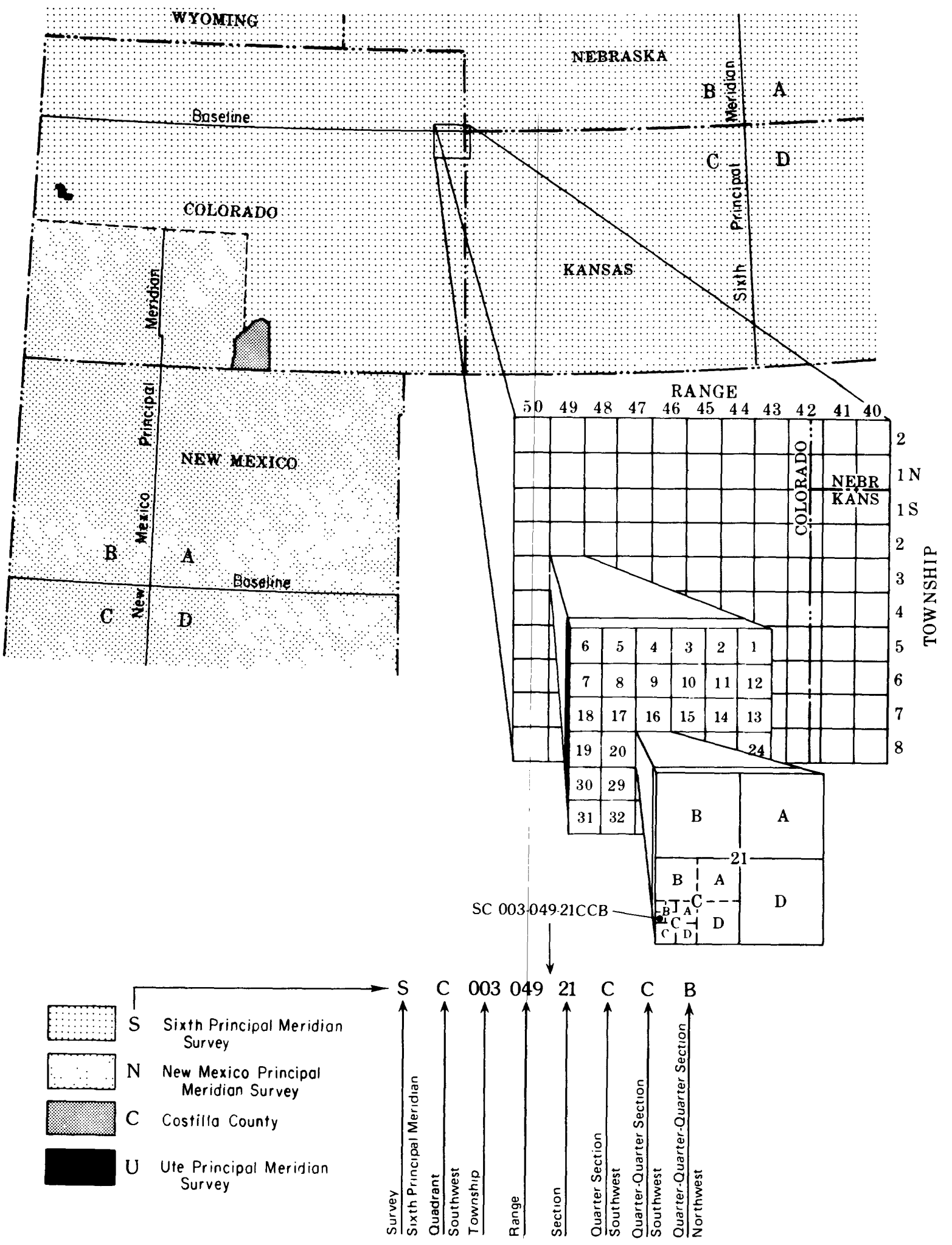

Figure 2.--System of numbering wells and springs. 


\section{REFERENCES}

Ackerman, D. J., and Rush, F. E., 1984, Hydrogeologic reconnaissance of the San Miguel River basin, southwestern Colorado, U.S. Geological Survey Open-File 84-4133, 25 p.

Skougstad, M.W., Fishman, M.J., Friedman, L.C., Erdmann, D.E., and Duman, S.S., 1979, Methods for determination of inorganic substances in water and fluvial sediments: U.S. Geological Survey Techniques of Water Resources Investigations, Book 5, Chapter A1, 626 p. 
HYDROLOGIC DATA 


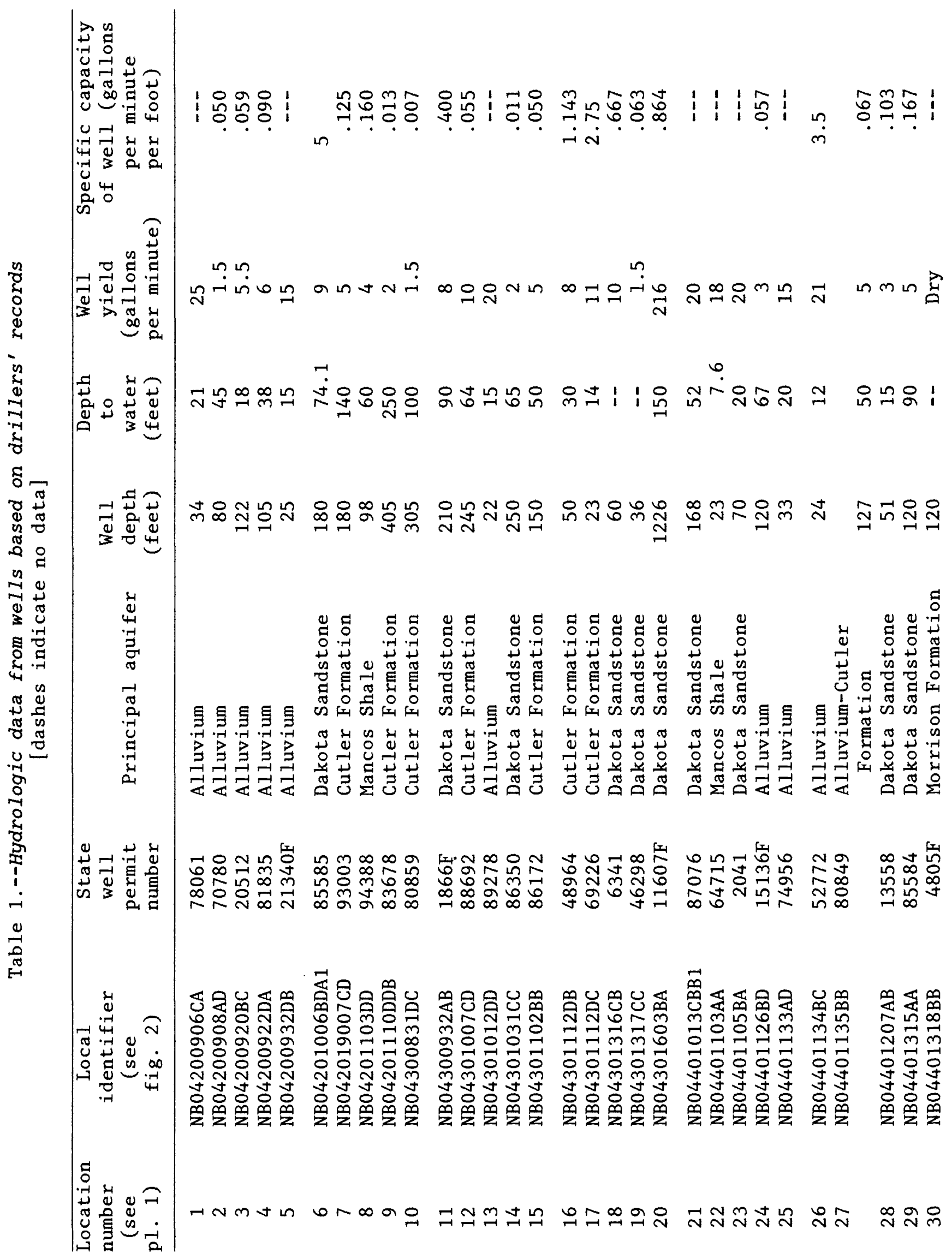




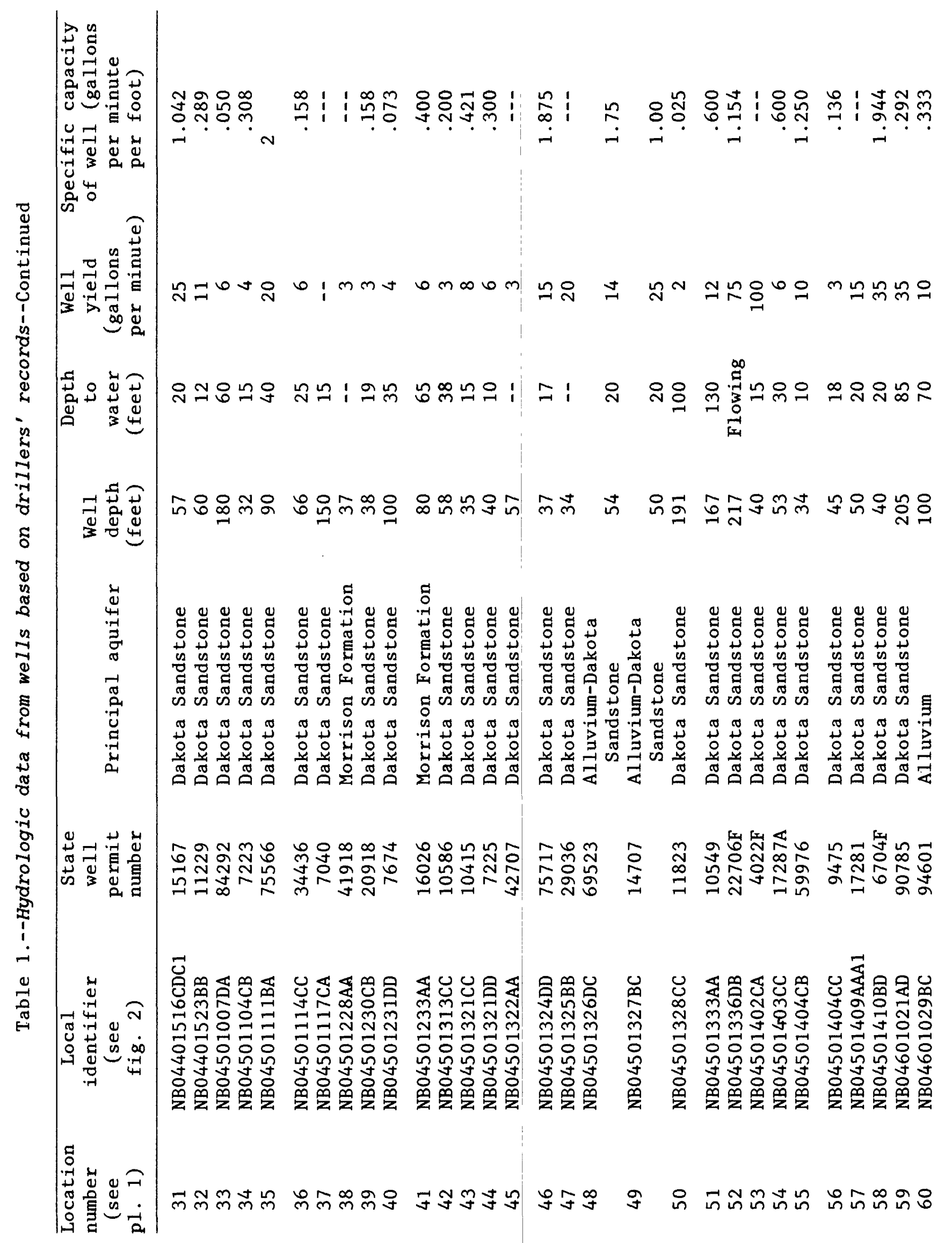




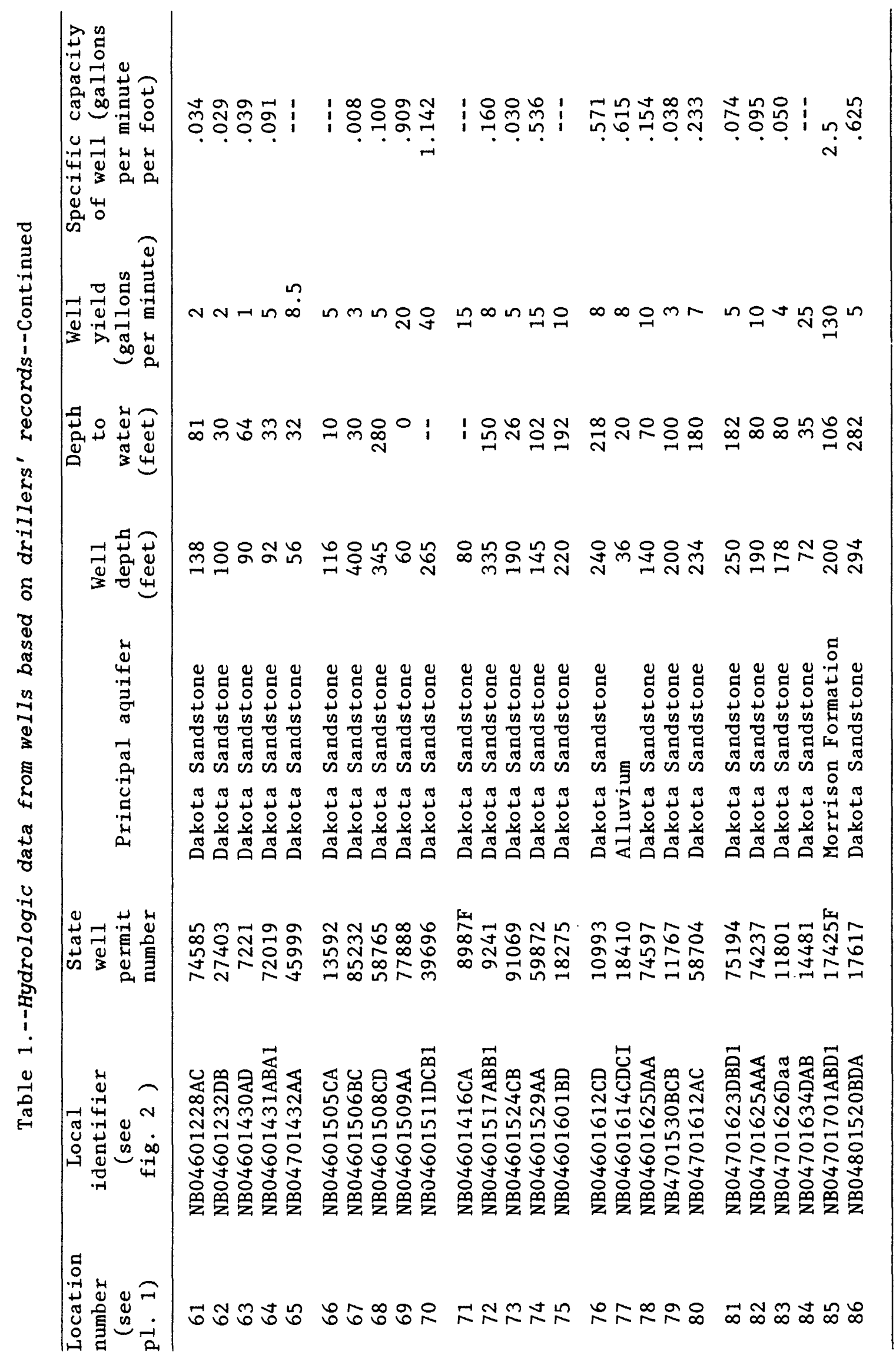




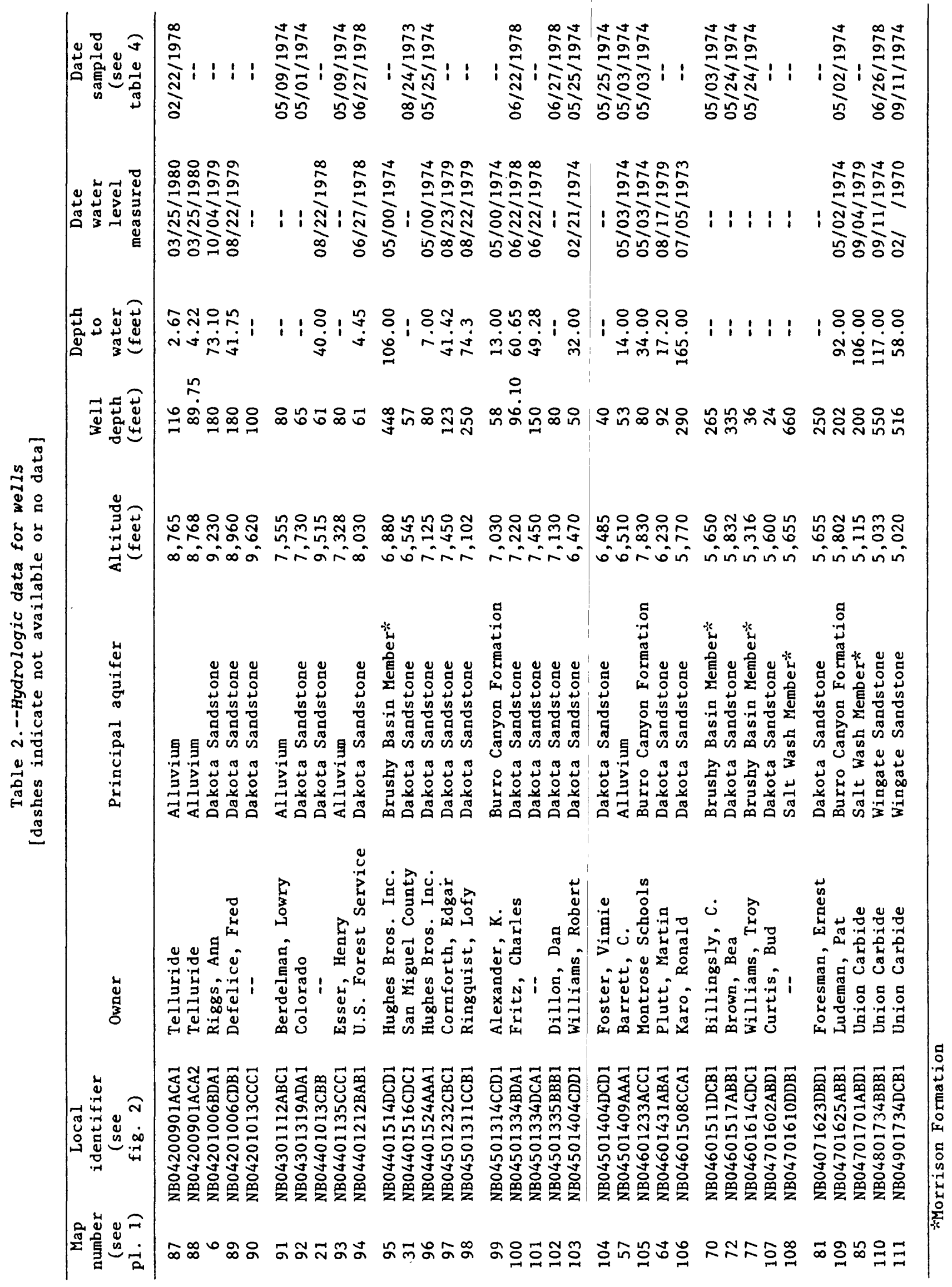




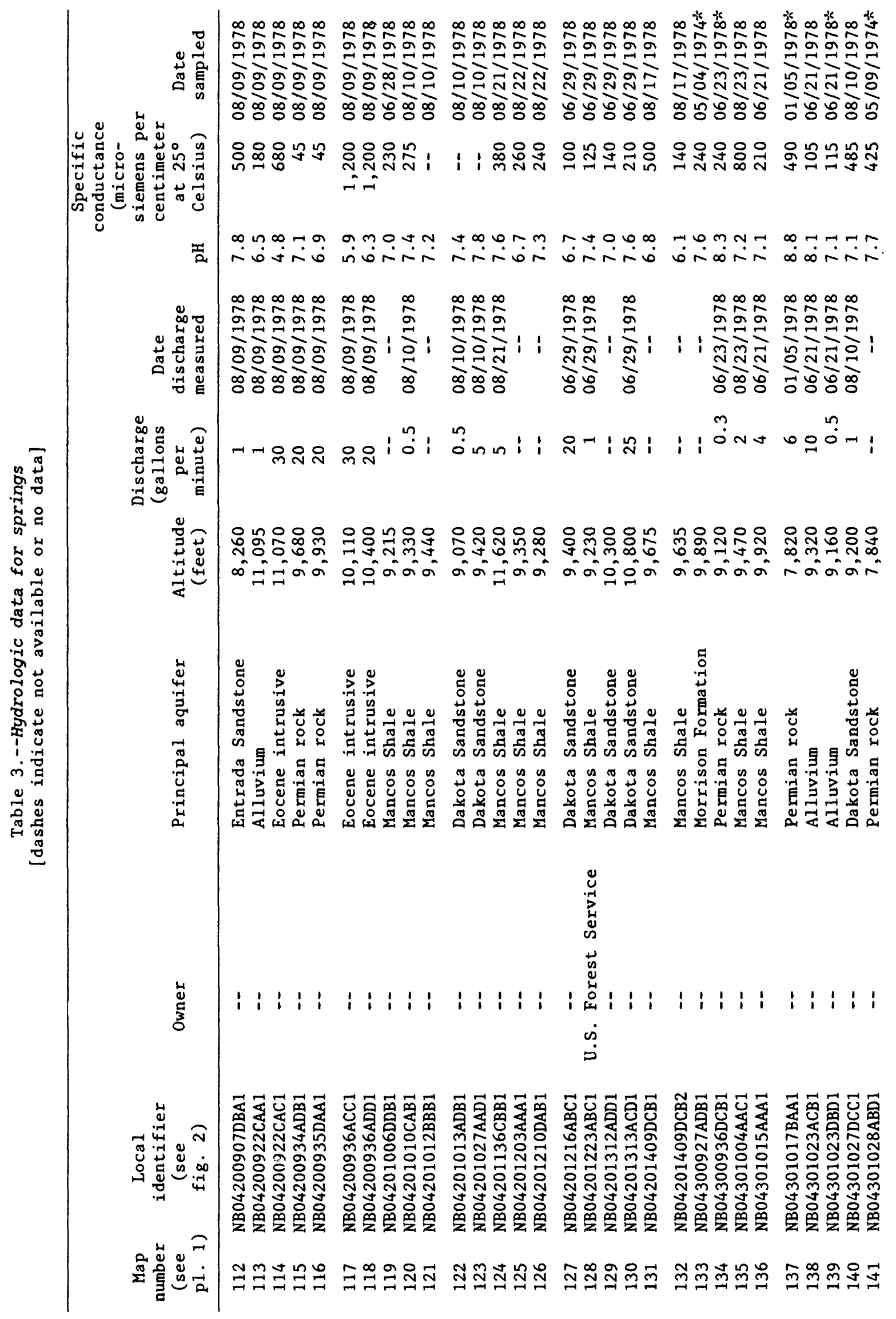




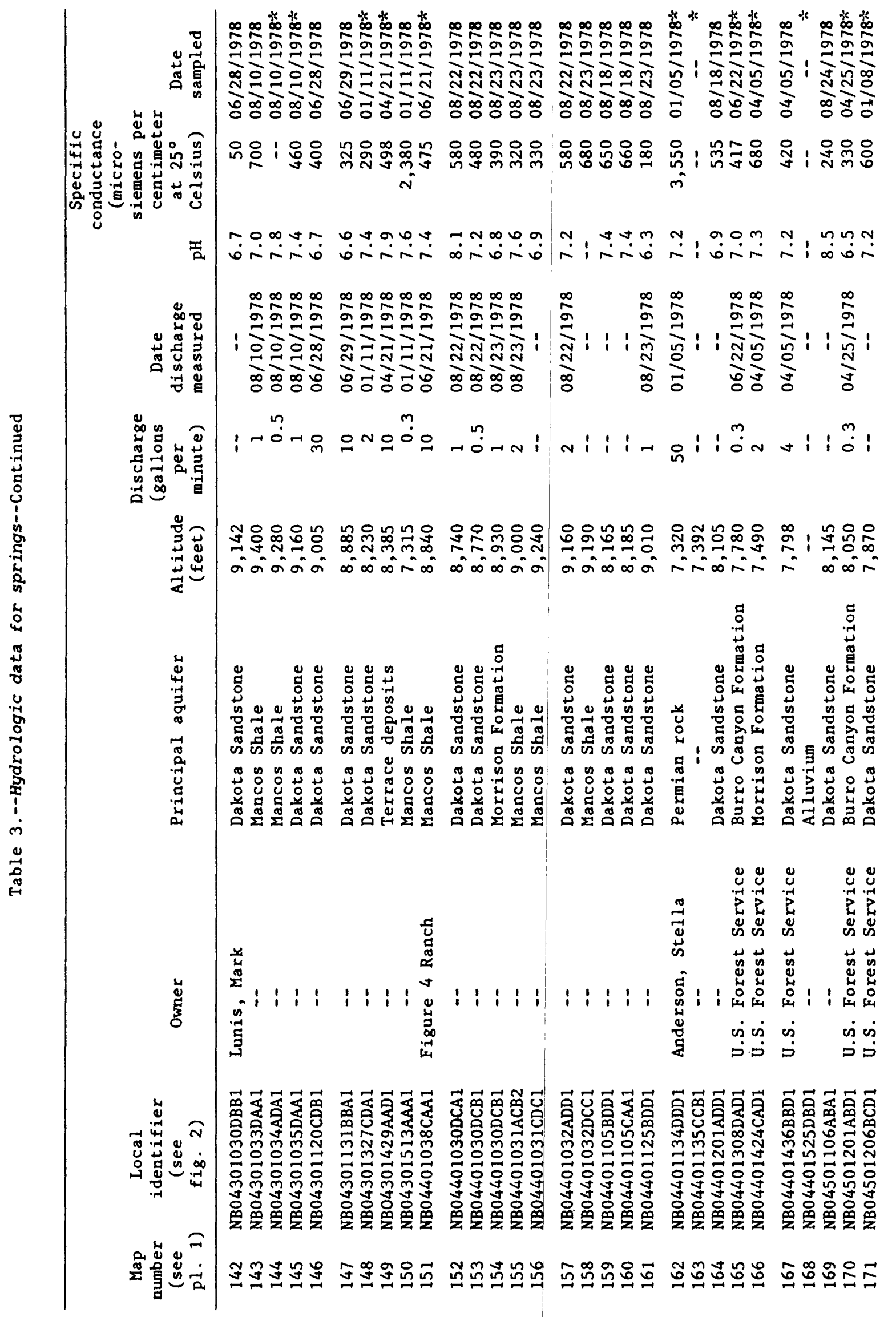




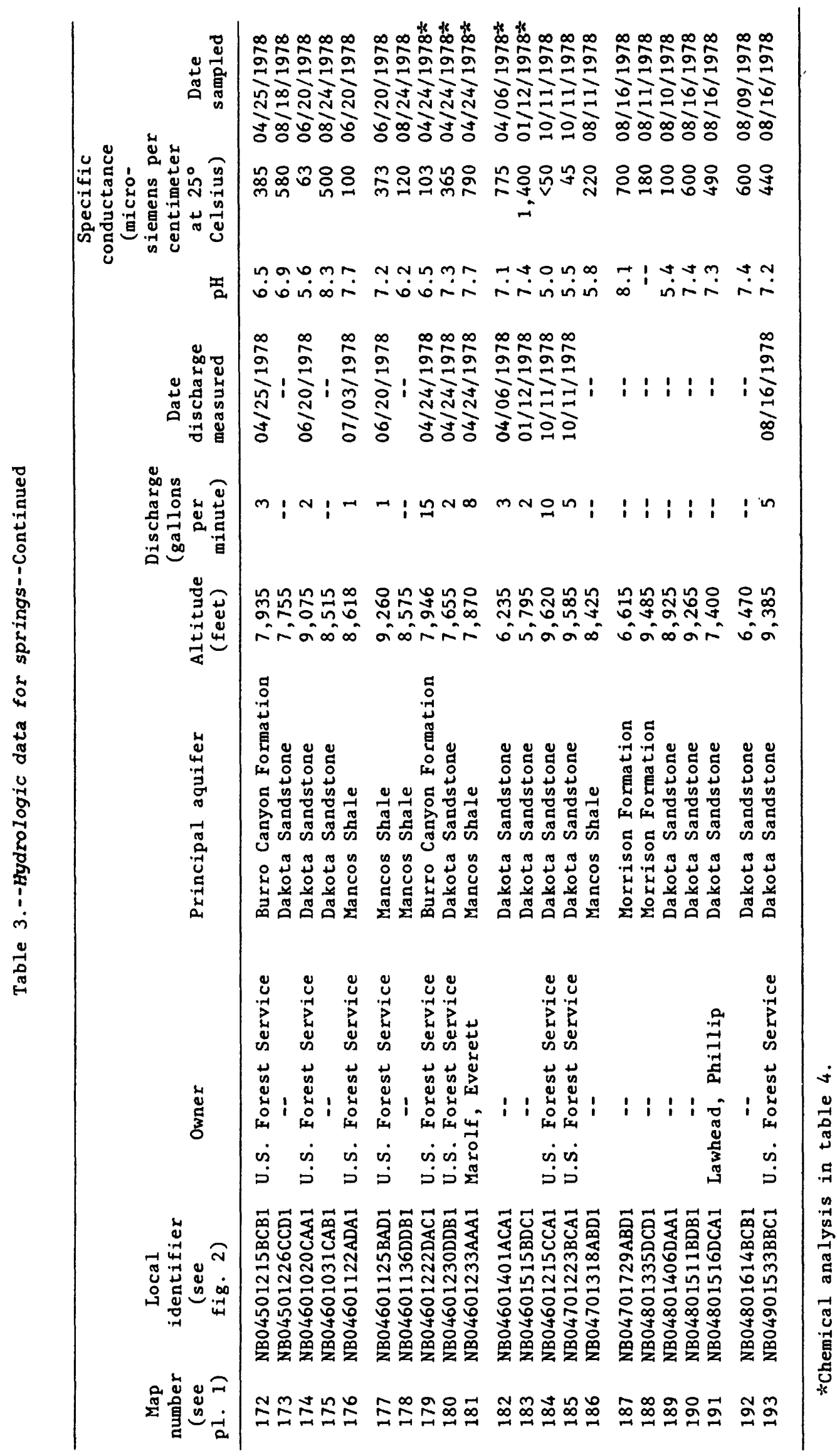




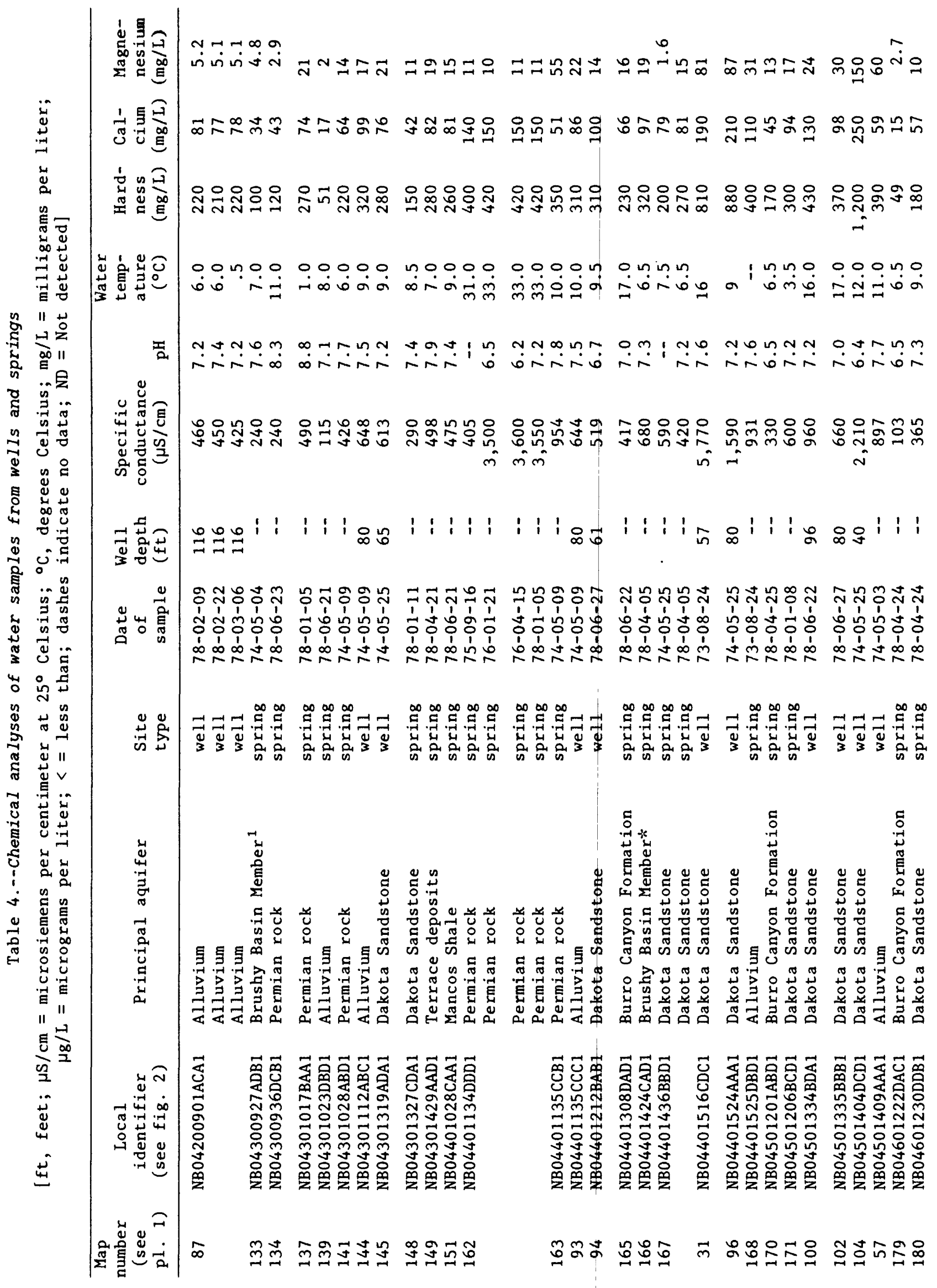




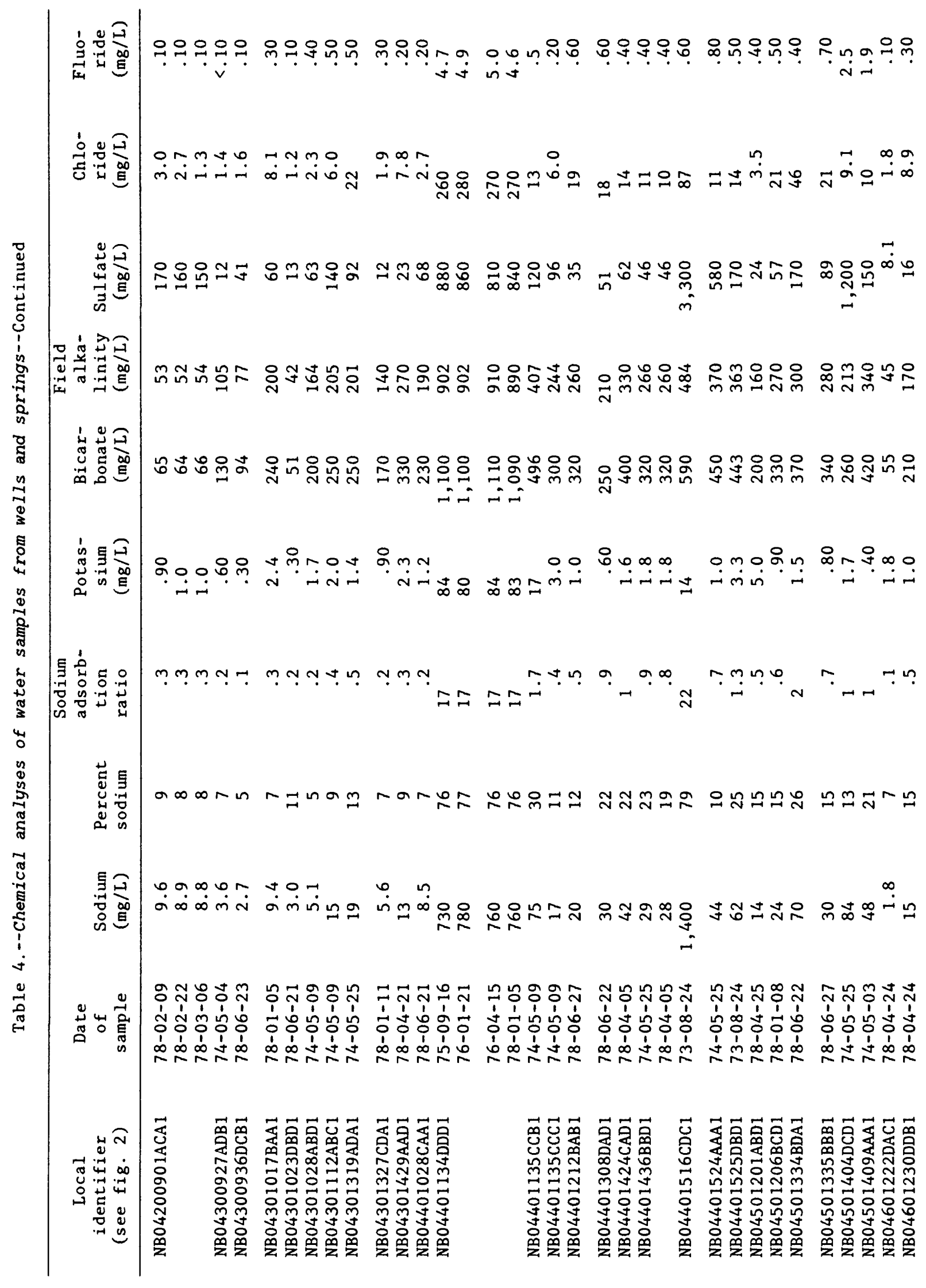




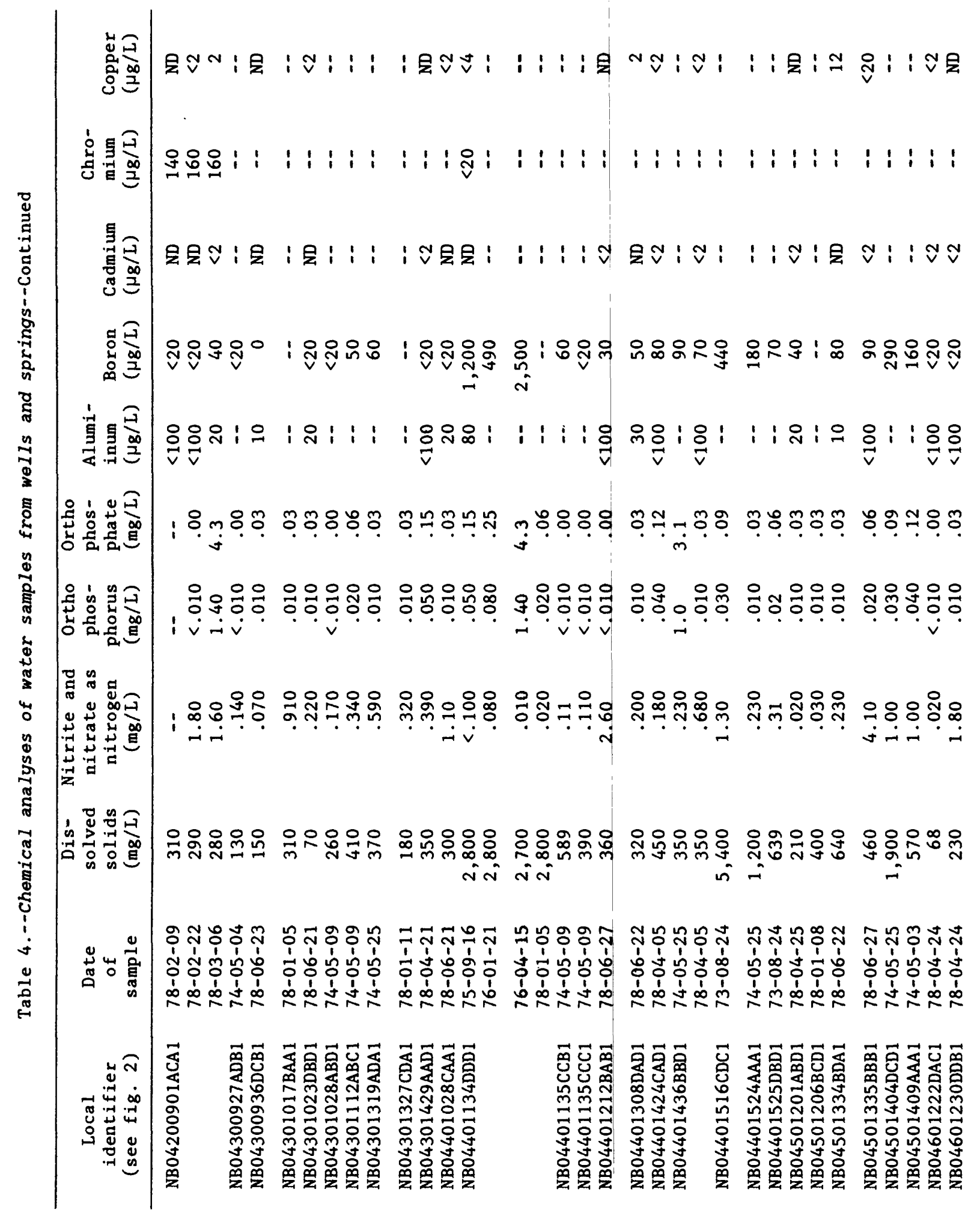




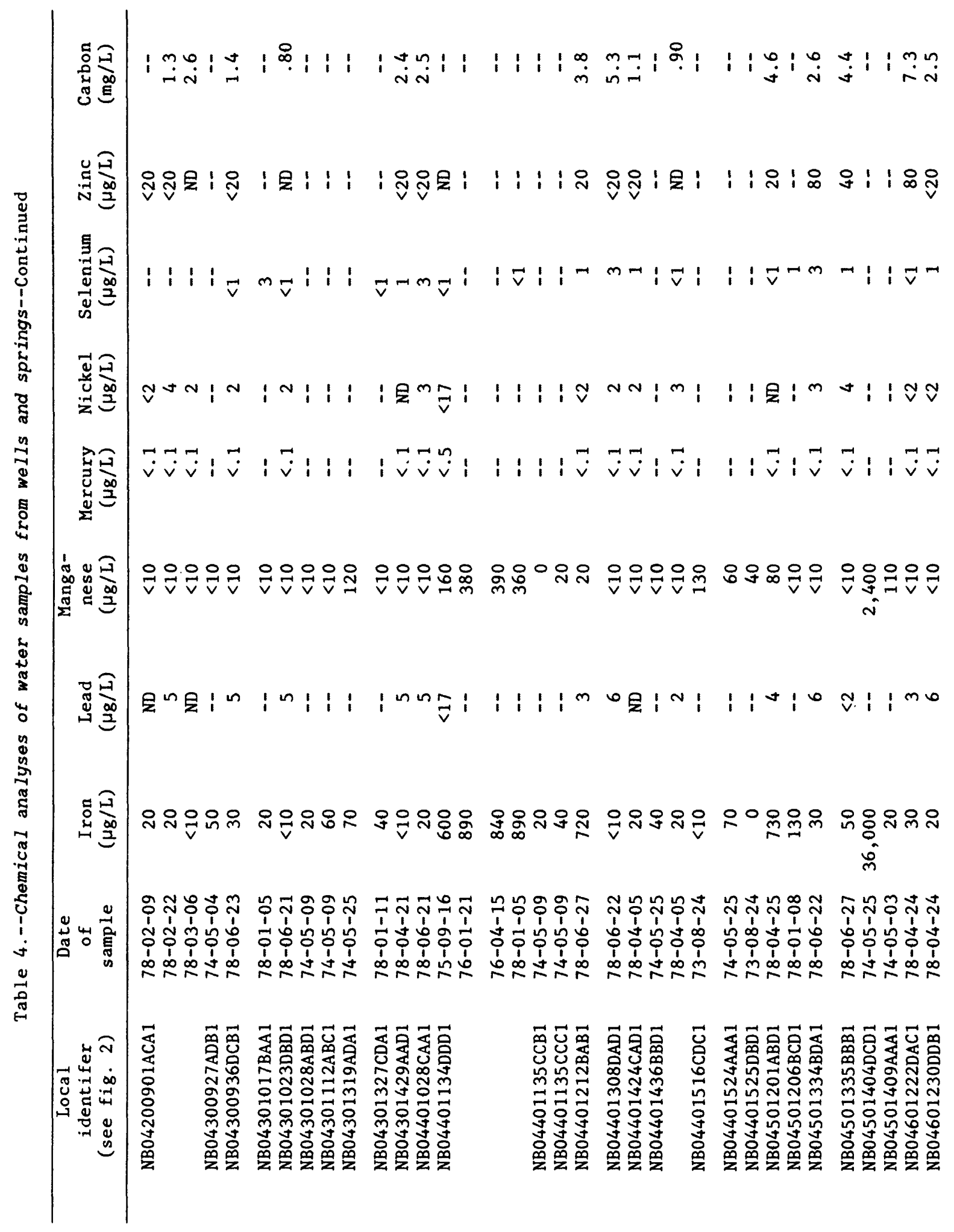



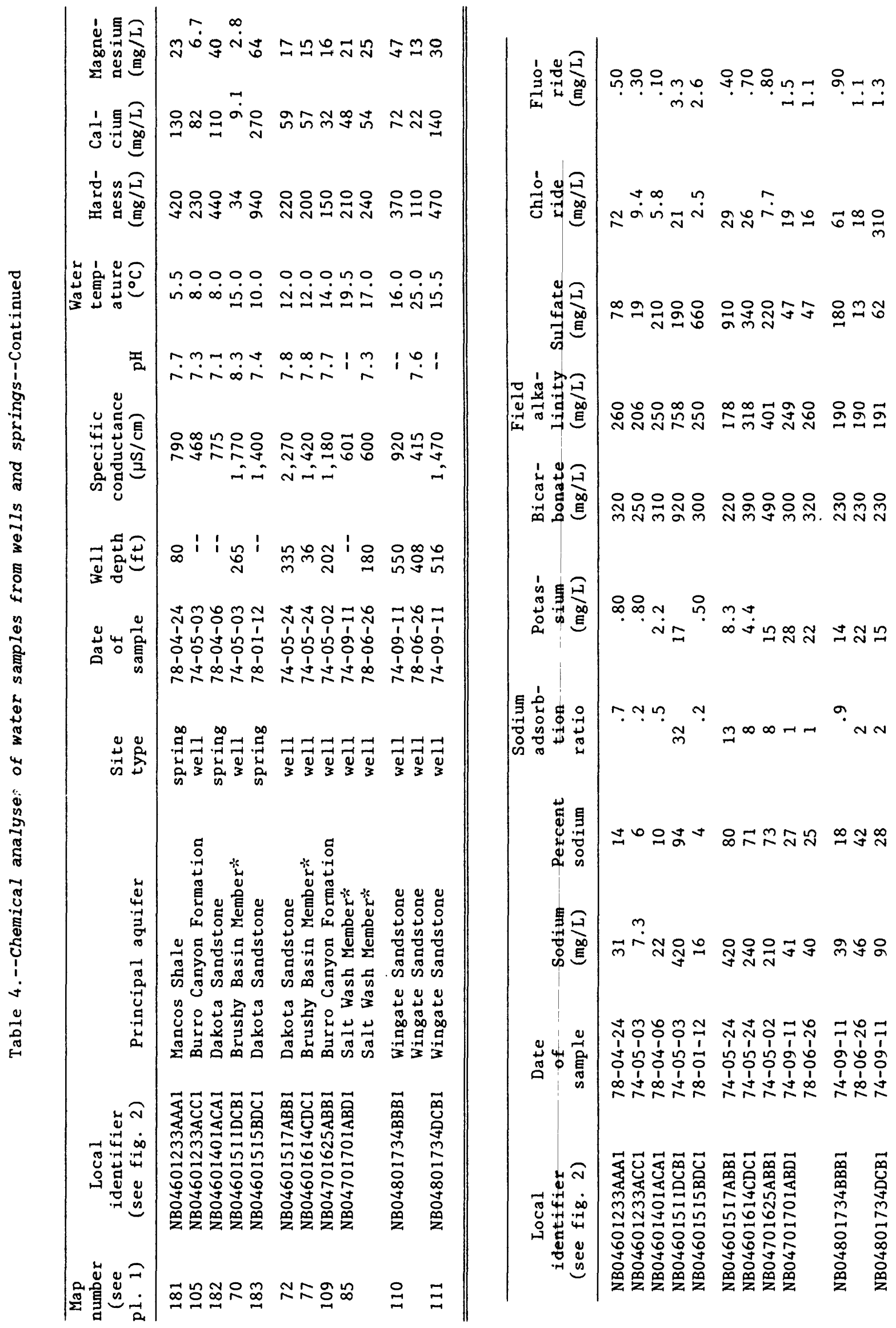


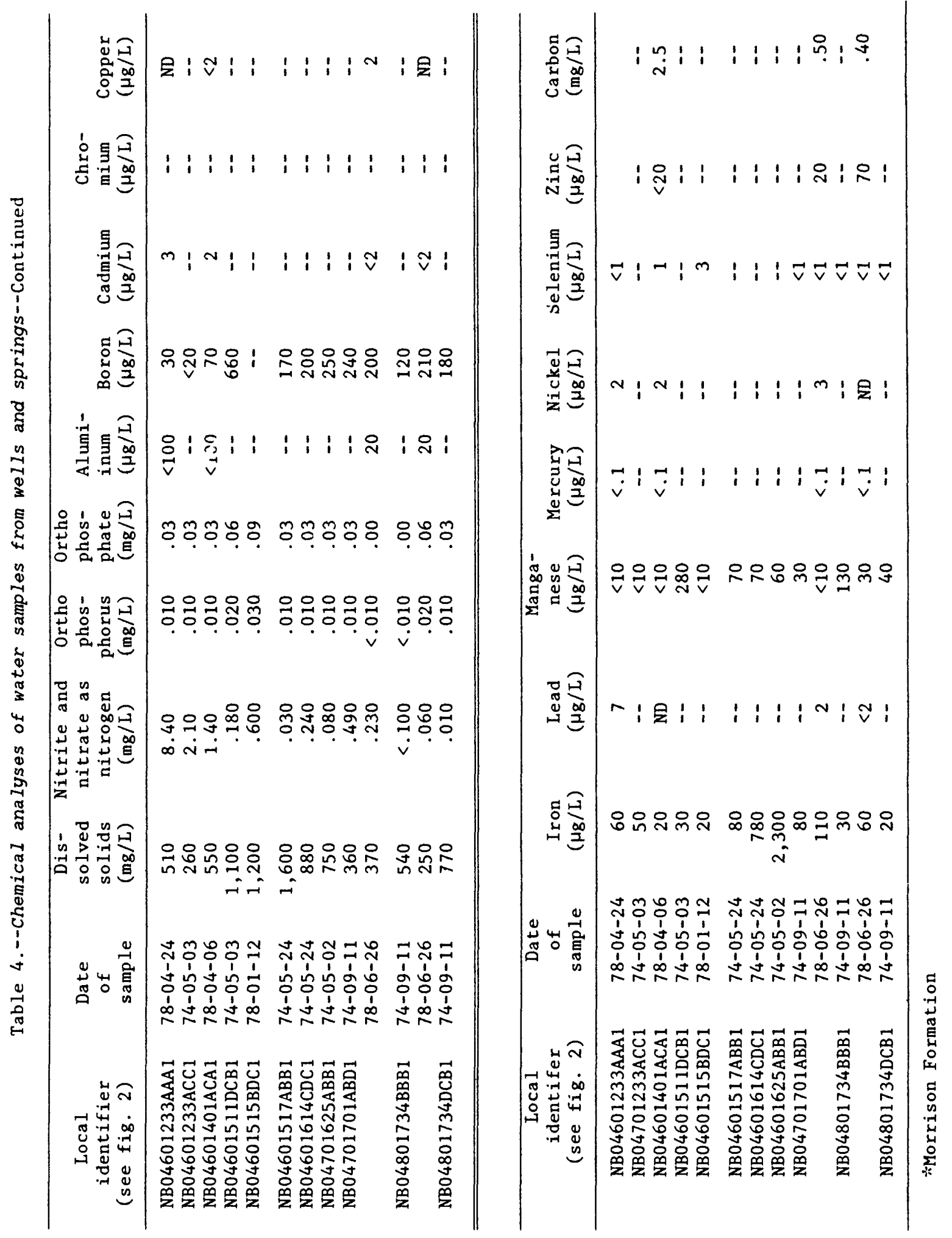

